\title{
PENERAPAN ETIKA KRISTEN DALAM PENDIDIKAN ANTI KORUPSI DI
}

\section{KELUARGA}

\author{
Penulis: Sapto Sunariyanti ${ }^{1}$
}

\begin{abstract}
Nowadays, coruption is present on Indonesia government bureaucracy, also exist in society. Corruption need to prevent as early as possible and start from smallest thing called family. This journal aim to explain about how to apllied Christian's ethics to anti-corruption education on

family. This topic analyze by biblical scripture approach and chistian's ethics. Bible tell implicitly that corruption is disobidience to the God by the story of Annanias and Safira also the story of Judas Iskaroit. Futhermore, corruption have the meaning of sin that must be accounted to the God personally. Conclusion, Christian's ethics that should be applied on anti-corruption education of family are involved honestly and integrity morals, the fear of the Lord understanding, and grateflul feelings.
\end{abstract}

Keywords: Christian ethics, education, corruption, family, character.

\begin{abstract}
Abstrak
Korupsi mewarnai berjalanannya birokrasi di Indonesia, bahkan terjadi pula di masyarakat dewasa ini. Tindak korupsi perlu diberantas sejak dini dan dimulai dari lini yang paling sempit yakni keluarga. Jurnal ini bertujuan untukmembahasbagaimana penerapan etika Kristen dalam pendidikan anti-korupsi di keluarga. Topik ini dianalisa menggunakan pendekatan alkitabiah dan etika Kristen. Alkitab menguak bagaimana kisah korupsi yang dilakukan Ananias dan Safira serta Yudas Iskariot yang merupakan suatu bentuk ketidaktaatan kepada Tuhan. Sehingga, korupsi memiliki makna dosa yang harus dipertanggung jawabkan oleh pelaku korupsi di hadapan Tuhan secara langsung. Kesimpulan yang diperoleh adalah pentingnya penerapan etika Kristen seperti moralitas kejujuran dan integritas, pemahaman takut akan Tuhan, serta pembelajaran mengucap syukur senantiasa dalam pendidikan anti-korupsi di keluarga.
\end{abstract}

Kata kunci: Etika Kristen, pendidikan, korupsi, keluarga, karakter.

${ }^{1}$ Sapto Sunariyanti adalah pengajar di Sekolah Tinggi Theologia Nazarene Indonesia yang menyelesaikan studi program S1 dan S2 program Magister Theologia di STTNI Yogyakarta. Selain sebagai pengajar juga menangani prodi Stratum Dua (S2) sebagai sekretaris prodi. Saat ini juga sebagai aktivis pelayanan dengan terlibat aktif dalam penggembalaan di Gereja Kristen Nazarene Agape Yogyakarta. 


\section{Pendahuluan}

Korupsi telah lama merajalela di birokrasi pemerintah bahkan terjadi juga kasus di kehidupan masyarakat tanpa diketahui publik. Laporan yang diperoleh dari Transparency International Indonesia Januari 2017, menyatakan bahwa Indonesia meraih posisi 90 peringkat Corruption Perception Index (CPI) di seluruh dunia. (lihat gambar 1) Kapolri Jenderal Pol. Tito Karnavian mengungkapkan bahwa pada tahun 2016, pihaknya telah menangani 756 perkara korupsi di seluruh Indonesia. ${ }^{2}$ Bahkan pada tutup tahun 2016 lalu, KPK (Komisi Pemberantasan Korupsi) berhasil meluncurkan OTT (Operasi Tangkap Tangan) yang menyergap beberapa kader partai anggota dewan. Sungguh prihatin melihat keadaan negeri ini.
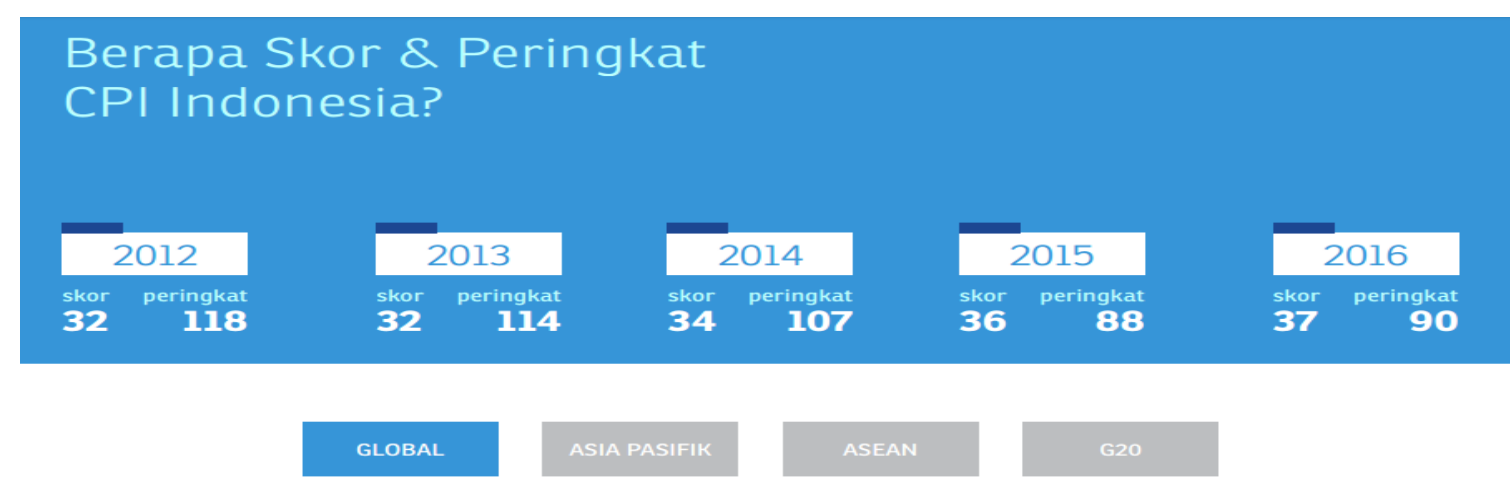

Naik 1

\section{Turun 2 \\ Peringkat}

\section{Gambar 1}

Skor dan Peringkat CPI Indonesia.

Sumber:

http://www.ti.or.id/media/documents/2017/01/26/c/o/corruption_perception_index_2016_design. pdf-2.pdf .

2

http://tv.kompas.com/read/2016/12/05/5235727948001/kapolri.sebut.tangani.756.kasus.korupsi.tahun.2016, (diakses tanggal 201 Februari 2017, puku 19.00 WIB). 
Pemerintah terus berusaha meningkatkan penanganan dan pencegahan korupsi di Indonesia dengan membentuk badan anti-korupsi seperti KPK (Komisi Penanggulangan Korupsi). Serta mengeluarkan kebijakan Undang- Undang pendukung pemberantasan korupsi, antara lain mencakup: ${ }^{3}$

Pertama, Undang-Undang No. 8 Tahun 1981 tentang Kitab Undang Undang Hukum Acara Pidana.

Kedua, Undang-Undang No. 28 Tahun 1999 Tentang Penyelenggaraan Negera yang Bersih dan Bebas dari Korupsi, Kolusi, dan Nepotisme.

Ketiga, Undang-Undang No. 31 Tahun 1999 Tentang Pemberantasan Tindak Pidana Korupsi.

Keempat, Peraturan Pemerintah No 71 Tahun 2000 Tentang Tata Cara Pelaksanaan Peran Serta Masyarakat dan Pemberian Penghargaan Dalam Pencegahan dan Pemberantasan Tindak Pidana Korupsi.

Kelima, Undang-Undang No. 20 Tahun 2001 tentang Perubahan atas UU Nomor 31 tahun 1999 tentang Pemberantasan Tindak Pidana Korupsi.

Keenam, Undang-Undang No. 30 Tahun 2002 Tentang Komisi Pemberantasan Tindak Pidana Korupsi.

Ketujuh, Undang-Undang No. 8 Tahun 2010 Tindak Pidana Pencucian Uang.

Kedelapan, Peraturan Pemerintah No. 63 Tahun 2005 tentang Sistem Manajemen Sumber Daya Manusia KPK.

\footnotetext{
${ }^{3}$ http://kpk.go.id/id/tentang-kpk/undang-undang-pendukung, (diakses tanggal 20 Februari 2017, pukul 19.00 WIB).
} 
Kesembilan, Undang-Undangn No. 46 Tahun 2009 tentang Pengadilan Tindak Pidana Korupsi.

Kesepuluh, Peraturan Pemerintah No. 103 Tahun 2012 tentang Perubahan Atas Peraturan Pemerintah No. 63 Tahun 2005 Tentang Sistem Manajemen Sumber Daya Manusia KPK.

Kesebelas, Undang-Undang No. 6 Tahun 2011 tentang Keimigrasian.

Pada dasarnya pembentukan karakter moral dan etika individu terletak pada keluarga. Apabila ingin mengurangi korupsi tak bisa hanya melakukan tindakan represif dan kuratif, namun diperlukan tindakan preventif sedini mungkin di masyarakat. Oleh sebab itu, diperlukan tindakan pembentukan karakter moral dan etika individu yang kuat melalui pendidikan anti-korupsi di keluarga. Pertanyaan yang muncul selanjutnya sebagai murid Kristus ialah, bagaimana menerapkan etika Kristen dalam pendidikan anti-korupsi di keluarga?

\section{Pembahasan}

\section{Pengertian Korupsi}

Kata "korupsi" menurut Kamus Besar Bahasa Indonesia berarti penyelewengan atau penyalahgunaan uang negara untuk keuntungan pribadi atau orang lain. ${ }^{4}$ Pakar Etika Kristen Dr. Robert Borrong dalam tulisannya menguraikan arti korupsi dari sudut etimologi kata sebagai berikut:

Korupsi menurut persepsi agama dan etika, bukanlah akibat melainkan hakikat dari manusia itu sendiri. Manusia pada hakekatnya korup. Kata korupsi berasal dari kata Latin corruptio/corruptionis artinya = merusak, membuat busuk, pembusukan, penyuapan. Kata Latin ini digunakan juga dalam Bahasa Inggris: Corruption, Bahasa

${ }^{4}$ Panitia Pengembangan Bahasa Indonesia Pusat Pembinaan dan Pengembangan Bahasa, Kamus Besar Bahasa Indonesia, (Jakarta: Balai Pustaka Departemen Pendidikan dan Kebudayaan), 2005, hal. 597. 
Belanda: Corruptie, kemudian Bahasa Indonesia menterjemahkannya dengan kata korupsi. ${ }^{5}$

Mengapa korupsi disebut hakekat manusia, hal tersebut berkaitan dengan sifat manusia yang memiliki kecenderungan untuk berbuat dosa. Sehingga korupsi tidak cukup hanya dipotong tetapi juga harus dicabut dari akarnya. Oleh karena pencabutan akar tidak mudah, maka pilihan yang terbaik adalah tindakan pencegahan sedini mungkin ketika manusia melalui proses pertumbuhan sejak kanak-kanak di tengah-tengah keluarganya. Dilihat dari sifatnya yang merusak maka korupsi merupakan perilaku dan tindakan yang tidak terpuji. Daya rusaknya merasuki berbagai aspek kehidupan dan merusak tatanan sosial. Berbagai aspek kehidupan dan tatanan sosial dimaksudkan mengindikasikan besarnya peran keluarga dalam pendidikan anti korupsi. Keluarga sebagai lembaga terkecil dalam masyarakat sangat berpengaruh dalam membentuk karakter moral anggotanya. Jika keluarga gagal maka akan berdampak pada karakter moral masyarakat. Bentuk-bentuk korupsi sendiri sebenarnya bermacam-macam. Ada korupsi uang, waktu, fasilitas dan sebagainya.

\section{Pengertian Etika Kristen}

Etika berasal dari kata Yunani yang hampir sama bunyinya, yaitu ethos yang berarti kebiasaan dan adat. Kemudian e'thos bermakna kesusilaan, perasaan batin atau kecenderungan hati seseorang melakukan perbuatan. ${ }^{6}$ Berbicara tentang etika tidak bisa dilepaskan dari moral, namun ruang lingkup etika lebih dalam ketimbang moral. Moral lebih mengarah pada perilaku

\footnotetext{
${ }^{5}$ Robert P. Borrong, Panorama Etika Praktis, (Jakarta: UPI STT Jakarta), 2011, hal. 115.

${ }^{6}$ Verkuyl, Etika Kristen Bagian Umum, (Jakarta: BPK Gunung Mulia), 2004, hal. 1.
} 
lahiriah seseorang/masyarakat, sedangkan etika menyentuh sampai kepada motivasi seseorang melakukannya.

Moral seseorang akan baik dipengaruhi karena memiliki etika yang baik. Dalam Bahasa Indonesia, istilah etika sering diartikan kesusilaan dengan demikian menjadi lebih mudah untuk melihat perbedaan makna moral dan etika meski keduanya tidak terpisahkan. Verkuyl lebih jelas mengatakan bahwa etika bukanlah ilmu pengetahuan yang bersifat deskripsi atau menguraikan perilaku/tindakan manusia, namun etika juga dipandang sebagai ilmu pengetahuan yang memaparkan masalah tentang apa yang baik sehingga bersifat normatif. ${ }^{7}$ Muncul pertanyaan maksud dari "apa yang baik" dipandang dari sudut pandang mana, karena ketika berbicara tentang apa yang baik ada banyak rujukan dan bisa bersifat relatif.

Namun oleh karena ruang lingkup karya ilmiah ini etika Kristen tentu saja dari sudut pandang iman Kristen yang didasarkan pada Alkitab Perjanjian Lama dan Perjanjian Baru termasuk pengajaran Yesus Kristus dalam Injil yang sarat nilai-nilai etis. Dengan demikian menurut etika Kristen segala sesuatu yang baik adalah yang sesuai dengan kehendak Allah. Seyogyanya pembahasan mengenai etika Kristen sendiri tidak bisa lepas dari pokok-pokok etika teologi, namun karena tulisan ini membatasi ruang lingkup penerapan etika dalam pendidikan anti korupsi di keluarga, maka tidak menguraikan etika pokok-pokok teologi secara panjang lebar tetapi menegaskan bahwa pendidikan anti korupsi di tengah-tengah keluarga didasarkan pada etika Kristen yang bersumber dari Alkitab sebagai terang dalam kehidupan keluarga-keluarga kristen.

Dari sudut pandang iman Kristen, Borrong mengatakan bahwa korupsi dipahami sebagai hakekat sekaligus sifat manusia dibawah pengaruh dosa (egois dan sombong) maka perbuatan

\footnotetext{
7 Ibid. hal. 3 .
} 
korup sebenarnya penyakit dalam yang berakar dari jiwa manusia yang rusak akibat dosa. ${ }^{8}$ Sehingga pengobatannya harus dibasmi sampai ke akar-akarnya dan dijaga jangan sampai tumbuh lagi. Lebih lanjut Borrong memaparkan pula bahwa jika dilihat dari sudut pandang moral, pemberantasan korupsi harus dimulai dengan pembinaan manusia sebagai makhluk yang karena anugerah Tuhan disembuhkan dan diselamatkan setelah mengambil komitmen untuk bertobat. ${ }^{9}$

Peran serta keluarga sangat besar pengaruhnya dalam melahirkan generasi yang takut Tuhan serta berintegritas supaya sanggup menangkal godaan-godaan dari berbagai jenis korupsi. Sehingga pendidikan anti korupsi di tengah keluarga yang akan menolong mengarahkan anggota keluarga agar memiliki sikap anti korupsi sangat penting diberikan sedini mungkin.

\section{Pentingnya Pendidikan Keluarga}

Dewasa ini terjadi perubahan gaya hidup di tengah-tengah masyarakat sebagai akibat dari kemajuan teknologi. Kemajuan tersebut membuat masyarakat mengikuti gaya hidup hedonisme dan konsumerisme. Kemajuan teknologi memang tidak selalu negatif ada banyak hal positifnya pula. Namun, ketika salah menyikapi akan berdampak pada pergeseran gaya hidup masyarakat dan akan menimbulkan masalah apabila masyarakat tidak dapat mengikuti perubahan tersebut karena keterbatasan materi. Di titik ini tingkat kemampuan ekonomi dan sosial menjadi sangat berpengaruh. Kondisi tersebut, jika secara keimanan tidak kuat akan berpotensi munculnya penyelewengan terkait dengan masalah pemenuhan kebutuhan materi guna mengikuti tren yang sedang berlaku. Korupsi bisa menjadi pilihan bagi yang lemah iman dan tidak takut Tuhan serta

\footnotetext{
${ }^{8}$ Robert P. Borrong. Panorama Etika Praktis, (Jakarta: UPI STT Jakarta), 2011, hal. 116.

${ }^{9}$ Ibid. hal. 118.
} 
memiliki kesempatan karena jabatan, wewenang dan kemudian disisi lain diperhadapkan pada "kebutuhan."

Oleh karena keluarga sebagai lembaga terkecil dalam masyarakat, maka peranannya dalam pola asah, asih dan asuh semakin penting. Khususnya berhubungan dengan pendidikan budi pekerti, akhlak dan etika. Terkait dengan persoalan korupsi, keluarga menjadi lembaga pertama yang seharusnya memberikan pendidikan dasar bahwa korupsi adalah tindakan yang menyalahi perintah Tuhan dan berdosa. Menurut Jonathan A. Trisna, orang tua memiliki peranan yang unik dalam pendidikan Kristen di dalam keluarga karena dalam keadaan yang wajar tidak ada orang lain yang mempunyai keintiman hubungan seorang anak dengan orang tuanya. ${ }^{10}$

Kedekatan relasi akan memudahkan proses pendidikan yang diterapkan orang tua baik yang positif maupun negatif, karena orang tua menjadi figur yang diteladani oleh anak-anaknya. Sehingga lebih lanjut, Jonathan A. Trisna mengatakan bahwa pengaruh iman Kristen tidak hanya dalam bentuk kata-kata atau nasehat namun juga harus mengajarkan Firman Allah melalui tingkah laku, sikap hidup, nilai-nilai serta cara berpikir. ${ }^{11}$ Orang tua bagaikan cermin bagi anak-anaknya karena apapun yang dilakukan akan ditiru dan diikuti oleh mereka.

Seperti yang disampaikan oleh Judy Ten Elshof berkaitan dengan pentingnya pendidikan kehidupan keluarga yang berpusat di rumah harus didasarkan pada teologi yang alkitabiah serta persekutuan yang kokoh antara Allah dan sesama. ${ }^{12}$ Melalui pernyataan tersebut jelas sekali betapa pentingnya peranan pendidikan rohani di tengah-tengah keluarga guna menciptakan pribadipribadi yang takut Tuhan dan memiliki integritas. Produk didikan keluarga tentu saja akan sangat

\footnotetext{
${ }^{10}$ Jonathan A. Trisna, Majalah Pelita Zaman No. 4, (Surabaya: Pusat Literatur Kristen), 1989, hal. 47.

11 Ibid. hal. 47.

12 Judy Ten Elshof, Fondasi Pendidikan Abad 21, (Malang: Gandum Mas), 2017, hal. 343.
} 
berdampak pada kehidupan sosial masyarakat. Mencakup didalamnya pengambilan keputusan etis ketika diperhadapkan pada godaan untuk mengambil kesempatan dalam kesempitan yang membawa mereka jatuh dalam dosa korupsi.

Mengutip pernyataan George Barna, Judy Ten juga berpendapat bahwa nilai nilai dan pandangan hidup yang menyatukan masyarakat yang sehat terbentuk dari rutinitas sehari-hari dan pilihan-pilihan keluarga. "Baik atau buruk, keluarga tetap menjadi batu penjuru dalam pembangunan sumber daya manusia. ${ }^{13}$ Jika keluarga sehat rohani maka masyarakat pun juga akan sehat rohaninya sehingga potensi kejahatan akan mudah ditekan. Ilmu sosiologi pun menggambarkan keluarga sebagai kesatuan pokok bagi seluruh masyarakat. ${ }^{14}$ Melalui pemaparan di atas jelas bahwa keluarga sebagai sentra dalam pembangunan sumber daya manusia maka hendaknya seluruh pendidikan yang menjunjung tinggi nilai-nilai etika Kristen diajarkan di sana, termasuk pendidikan anti korupsi yang didasarkan pada kebenaran Firman Tuhan karena:

Secara historis, keluarga telah memiliki pengaruh yang kuat pada masyarakat. Banyak dari masalah sosial besar yang jelas saat ini mencerminkan nilai-nilai dan kualitas kehidupan keluarga. Nilai tradisional seperti menghormati otoritas, standar perilaku moral, mengajarkan tentang benar dan salah, tidak curang dan berdusta, dan sebagainya adalah nilai-nilai yang seharusnya dikomunikasikan kepada anak-anak dari orang tua mereka dalam lingkungan rumah. ${ }^{15}$

Dengan demikian tidak dipungkiri lagi bahwa pendidikan didalam keluarga sangat penting karena berperan membentuk anggotanya dengan nilai-nilai etis yang benar menurut Firman Tuhan sehingga berdampak kehidupan rohani serta menjadi terang di tengah-tengah masyarakat.

${ }^{13}$ Judy Ten, Fondasi Pendidikan Abad 21 mengutip George Barna, The Second Coming of the Church, (Nashville: Word), 1998, hal. 190.

${ }^{14}$ Homrighausen dan Enklaar, Pendidikan Agama Kristen, (Jakarta: BPK Gunung Mulia), 1993, hal. 144.

${ }^{15}$ Judy Ten Elshof, Editor Michael J. Anthony, Fondasi Pendidikan Abad 21, (Malang: Gandum Mas), 2017, hal. 350. 
Memiliki kemampuan untuk berkata tidak terhadap dosa termasuk segala bentuk korupsi dan kecurangan yang merugikan pihak lain, lembaga tempat mereka bekerja serta negara.

\section{Bagaimana Alkitab dan Etika Kristen Memandang Korupsi Dan Penerapan Dalam}

\section{Keluarga}

Penerapan etika Kristen dalam pendidikan anti korupsi di keluarga tentu saja harus dimulai dengan apa kata Alkitab. Meski istilah korupsi itu sendiri tidak ditulis secara langsung, namun kasus yang dapat dikategorikan dengan korupsi dan segala jenis bentuknya dapat ditemukan dalam Alkitab. Perintah yang paling jelas disampaikan Alkitab adalah jangan mencuri (Ulangan 5:19), korupsi tidak berbeda dengan mencuri karena mengambil uang yang bukan milik sendiri.

Kisah Ananias dan Safira dalam Kisah Para Rasul 5:1-11 menjelaskan bahwa praktek korupsi juga terjadi di jaman para rasul. Disana tergambar bentuk korupsi yang dilakukan Ananias dan Safira dengan menahan hasil penjualan sebidang tanah, yang sesuai kesepakatan awal mestinya dibawa seluruhnya di depan kaki rasul-rasul dan kemudian dibagi kepada semua yang membutuhkan, tetapi justru ditahan sebagian untuk kepentingan pribadi.

Kemudian kisah lain yang juga menggambarkan tentang dosa sejenis korupsi adalah suap yang terdapat dalam Lukas 22: 3-6 tentang pengkhianatan Yudas dengan cara menyerahkan Yesus kepada imam-imam kepala dan ia menerima sejumlah uang untuk hal tersebut. Dalam kasus tersebut para imam kepala berhasil menyuap Yudas. Dalam Injil Yohanes 12:6 disebutkan bahwa berhubungan dengan tanggungjawabnya sebagai bendahara, Yudas sering tidak jujur dengan cara mencuri uang kas. Sehingga dapat disimpulkan memang ada penyakit rohani yang perlu diatasi dalam diri Yudas, begitu juga ketidakjujuran Ananias dan Safira. 
Kedua kisah tersebut menunjukkan perlunya keterlibatan Roh Kudus dalam membangun karakter rohani seseorang menjadi seperti karakter Kristus. Memang pembangunan karakter rohani umat menjadi bagian tugas para pembimbing rohani di gereja, namun peranan keluarga tidak kalah penting. Bahkan ranah di ranah keluarga kontrol lebih mudah dilakukan. Dengan bimbingan yangmengarah padapembentukan karakter Kristus serta merta menjadi dasar yang kuat bagi penyampaian pendidikan anti korupsi di tengah keluarga. Sehingga lebih mudah diterima dan diterapkan ditengah himpitan pengaruh buruk dari lingkungan yang sudah terpengaruh dengan sekularisme dan materialisme.

Di sisi yang lain perbuatan korupsi juga menyatakan adanya keraguan terhadap pemeliharaan Tuhan dalam pemenuhan kebutuhan padahal dalam Filipi 4:19 sangat jelas dikatakan bahwa Allah akan memenuhi seluruh keperluan menurut kekayaan dan kemuliaanNya. Selain keraguan dan ketidakpuasan akan berkat Tuhan yang telah diterima juga menggambarkan sulitnya mengucap syukur. Dalam hal ini tampak bahwa karakter merasa cukup harus dimiliki oleh setiap orang dan hanya iman yang berpusat pada Allah yang menjadi kuncinya. Bagian Firman Tuhan yang memberi peringatan tentang hal itu mengatakan "Janganlah kamu menjadi hamba uang dan cukupkanlah dirimu dengan apa yang ada padamu” (Matius 5:10).

Penting untuk dipahami oleh setiap orang percaya bahwa korupsi juga merupakan bentuk Ketidaktaatan terhadap Allah. Melakukan berarti melanggar perintah Allah sendiri, dan Alkitab mencatat dengan jelas bahwa setiap pelanggaran terhadap hukum Allah harus dipertanggungjawabkan dan ada konsekuensi yang akan diterima. Jadi hal tersebut juga harus ditanamkan dalam keluarga. Di dalam Ulangan 6:6-7, Alkitab mengajarkan bahwa setiap orang tua wajib mengajarkan secara berulang-ulang segala perintah Tuhan kepada anak-anak yang telah dititipkan di tengah-tengah keluarga serta memperhatikan tingkah lakunya sehari-hari supaya tidak 
serupa dengan dunia ini dan tahu membedakan mana kehendak Allah, apa yang baik, yang berkenan kepada Allah dan yang sempurna ( Roma 12:2). Disini juga ada peranan etika Kristen yang menjelaskan bahwa dalam hidup manusia yang berdosa ada suara hati yang mengingatkan bahwa manusia diciptakan segambar dan serupa dengan Allah.

Namun sebagai orang percaya suara hati kita harus merupakan hasil produk pertobatan yang dikerjakan oleh: sehingga acuan baik atau buruk serta benar atau tidaknya sebuah perbuatan didasarkan pada apa yang menjadi kehendak Allah. ${ }^{16}$ Diharapkan pemahaman ini akan memotivasi setiap keluarga untuk mendidik anggota keluarganya dalam kebenaran Firman Tuhan sehingga moralitas kejujuran dan intergritas menjadi gaya hidup dalam keseharian baik didalam rumah maupun di lingkungan masyarakat. Dengan mengingat perkataan Paulus dalam 2 Timotius 3:1517:

Ingatlah juga bahwa dari kecil engkau sudah mengenal Kitab Suci yang dapat memberi hikmat kepadamu dan menuntun engkau kepada keselamatan oleh iman kepada Kristus Yesus. Segala tulisan yang diilhamkan Allah memang bermanfaat untukmengajar, menyatakan kesalahan, untuk memperbaiki kelakuan dan untuk mendidik orang dalam kebenaran. Dengan demikian tiap-tiap manusia kepunyaan Allah diperlengkapi untuk setiap perbuatan baik. ${ }^{17}$

\section{Kesimpulan}

Keluarga harus menjadi tempat utama bagi penerapan pendidikan moral dan karakter yang berintegritas dan anti korupsi bagi setiap anggotanya. Solusi bagi pencegahan terjadinya korupsi dimulai dari keluarga yang memiliki fondasi Alkitabiah untuk menghadapi pengaruh hedonisme di dunia modern saat ini yang cenderung menyeret pada penyalahgunaan kekuasaan demi

\footnotetext{
${ }^{16}$ J. Verkuyl, Etika Kristen Bagian Umum, (Jakarta: BPK Gunung Mulia), 2004, hal. 60.

${ }^{17}$ Alkitab.
} 
kenikmatan. Penerapan moralitas kejujuran dan sikap bertanggungjawab yang dibungkus dalam etika Kristen di keluarga akan berhasil jika diterangi Roh Kudus sehingga masing-masing menjadikan hidup takut akan Tuhan dan suka mengucap syukur serta merasa cukup sebagai gaya hidup.

Pada akhirnya dapat ditarik kesimpulan bahwa penerapan pendidikan anti korupsi adalah hasil bingkaian secara komprehensif antara kebenaran Alkitab dan etika Kristen yang tidak dapat dipisahkan satu dengan yang lain. Katakan TIDAK pada KORUPSI bukan hanya slogan lagi tetapi menjadi tindakan yang tidak berat dilakukan bahkan bisa memerangi praktek korupsi yang terjadi di lingkungan masyarakat dan negara. 


\section{DAFTAR PUSTAKA}

Ali, Hasan \& Tim Redaksi Pusat Bahasa Depdiknas, Kamus Besar Bahasa Indonesia Edisi Ketiga, Jakarta: Balai Pustaka, 2005.

Anthony, J. Michael, Fondasi Pendidikan Abad 21, Malang: Gandum Mas, 2017.

Borrong, P. Robert. Panorama Etika Praktis, Jakarta: UPI STT Jakarta, 2011.

Brownlee, Malcolm. Pengambilan Keputusan Etis, Jakarta: BPK Gunung Mulia, 2009.

Conn. M. Harvie, Teologia Kontemporer, Malang: SAAT, 2000.

Darmaputera, Eka. Etika Sederhana Untuk Semua, Jakarta: BPK Gunung Mulia, 2009.

Enklaar, I.H. dan, Homrighausen, Pendidikan Agama Kristen, Jakarta: BPK Gunung Mulia, 1993.

Jongeneel, J.A.B., Hukum Kemerdekaan, Jakarta: BPK Gunung Mulia, 1980.

Suseno, Frans Magnis. Etika Dasar, Yogyakarta: Kanisius, 1987.

Trisna, Jonathan, A. Majalah Pelita Zaman No. 4, Surabaya: Pusat Literatur Kristen, 1989.

Verkuyl, J. Etika Kristen Bagian Umum, Jakarta: BPK Gunung Mulia, 2004.

Website

http://kpk.go.id/id/tentang-kpk/undang-undang-pendukung

http://tv.kompas.com/read/2016/12/05/5235727948001/kapolri.sebut.tangani.756.kasus.korupsi.t $\underline{\text { ahun. } 2016}$

http://www.ti.or.id/media/documents/2017/01/26/c/o/corruption_perception_index_2016_design. pdf-2.pdf. 